\title{
THE INFLUENCE OF EXERCISE ON THE NEUROMUSCULAR ACTIVITY OF RELAXANT DRUGS*
}

\author{
Francis F. Foldes, Almiro P. Monte, H. M. Brunn, Jr., and \\ BERNARD WOLFSON'
}

A RECENT SURVEY of the literature ${ }^{l}$ revealed little information on the influence of exercise on the course of the neuromuscular block induced in man by quaternary ammonium-type relaxants. Consequently, observations on the effects of the rate of exercise on the partial neuromuscular block were included in a comparative study ${ }^{2}$ carried out with five rellaxants in unanaesthetized human subjects.

\section{Material and Methods}

This investigation was carried out in five male and five female healthy, adult volunteers. The relaxants studied were d-tubocurarine chlorine $\left(\mathrm{d}-\mathrm{Tc}_{\mathrm{c}}\right)$, toxiferine chloride (toxiferine), $\neq^{3}$ gallamine triethiodide (gallamine), decamethonium bromide $(\mathrm{ClO})$, and succinylcholine $(\mathrm{SC} h)$. In preliminary studies, the dose of each drug which produced a 90 to 95 per cent decrease of the grip strength, or a 50 to 55 per cent decrease of vital capacity, whichever was greater, was selected. The enzymatic hydrolysis of SCh was prevented by the intravenous administra. tion of $0.3 \mathrm{mg} . / \mathrm{kg}$. of hexalluorenium," a selective inhibitor of plasma cholinesterase. The doses of the relaxants studied are presented in Table I.

TABLE L

The Dose of The Relaxants STUDIED

\begin{tabular}{lc}
\hline Compound & $\begin{array}{c}\text { Dose } \\
\text { microgm./kg. }\end{array}$ \\
\hline d-Tc & 100 \\
Grallamine & 700 \\
Toxiferine & 15 \\
ClO & 27 \\
SCh & 80 \\
\hline
\end{tabular}

*Administered five minutes after the intravenous injection of 0.3 $\mathrm{mg} . / \mathrm{kg}$. hexafuorenium.

With one exception, two experiments were carried out with each of the five relaxants on all subjects. With toxiferine, however, one of the ten original subjects, who became unavailable before the termination of the study, was

*Read at the Second World Congress of Anaesthesiologists, Toronto, September, 1960.

†From the Department of Anesthesiology, Mercy Hospital, and the Section on Anesthesiology, Department of Surgery, University of Pittsburgh School of Medicine, Pittsburgh, Penn.

†Toxiferine chloride was obtained through the courtesy of Dr. Leo A. Pirk of Hoffman-LaRoche Inc., Nutley, New Jersey.

Can. Anaes. Soc. J., vol. 8, no. 2, March, $19 \phi 1$. 
replaced by another volunteer. Grip strength. (measured by a dynamometer) was determined immediately before and after exercise consisting of the squeezing of the bulb of an ergograph* apparatus for one minute with the maximum effort of which the subject was capable, before and at three, six, and ten minutes after the start of the injection of the relaxant, and at five minute intervals thereafter. With each relaxant, the subjects exercised at the rate of six per minute on one occasion and at 60 per minute on another. Vital capacity, measured with a Bennett or Dheger ventilation meter, as well as blood pressure, pulse, and respiratory rate, were also recorded at appropriate intervals. The experiments, with a few exceptions, were carried out until grip strength returned to 75 per cent of control.

\section{Results}

There were marked differences between the effects of the non-depolarizing (d-Tc, toxiferine, and gallamine) and the depolarizing relaxants ( $\mathrm{ClO}$ and $\mathrm{SCh}$ ). The non-depolarizing relaxants affected grip strength much more than vital capacity. In contrast, there was relatively little difference in the effects of the

\section{d-TUBOCURARINE CHLORIDE (100MGM/KG)}

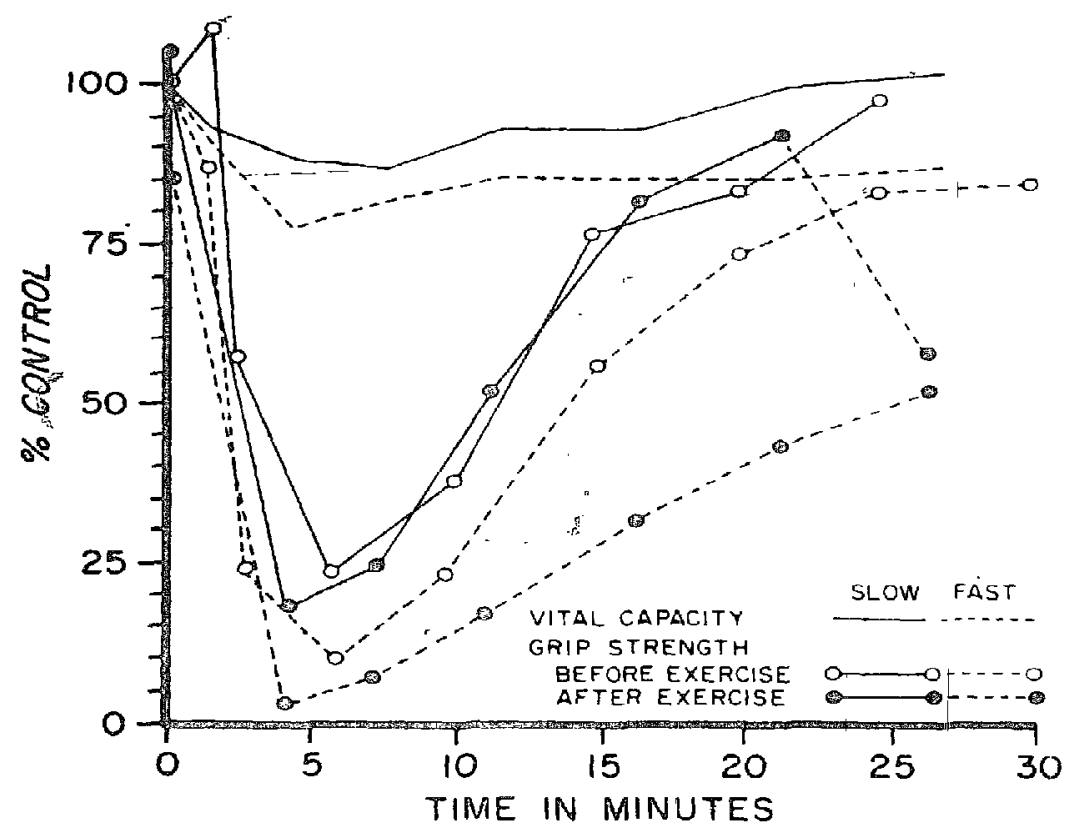

FigurE 1. Effect of the rate of exercise on grip strength after the administration of $100 \mathrm{microgm} . / \mathrm{kg}$. d-Tc. The curves (also in Figures $2,3,4$, and 5 ) represent the averages obtained in teh subjects.

depolarizing relaxants on grip strength and vital capacity. No significant difference was found in the magnitude of grip strength before and after exercise at a slow rate (six per minute) with either the non-depolarizing or the depolarizing relaxants. (See Figs. 1, 2, 3, 4, and 5.) After exercise at the fast rate, however, the grip strength at comparable times was significantly less after exercise if a

*Obtainable from Fred J. Christensen, Physiological Apparatus, Watertown, Massachusetts. 
non-depolarizing relaxant was used (Figs. 1, 2, and 3). No such difference was found when the experimental subjects received a depolarizing relaxant (Figs. 4 and 5).

\section{TOXIFERINE DICHLORIDE ( $15 \mu \mathrm{GM} / K G)$}

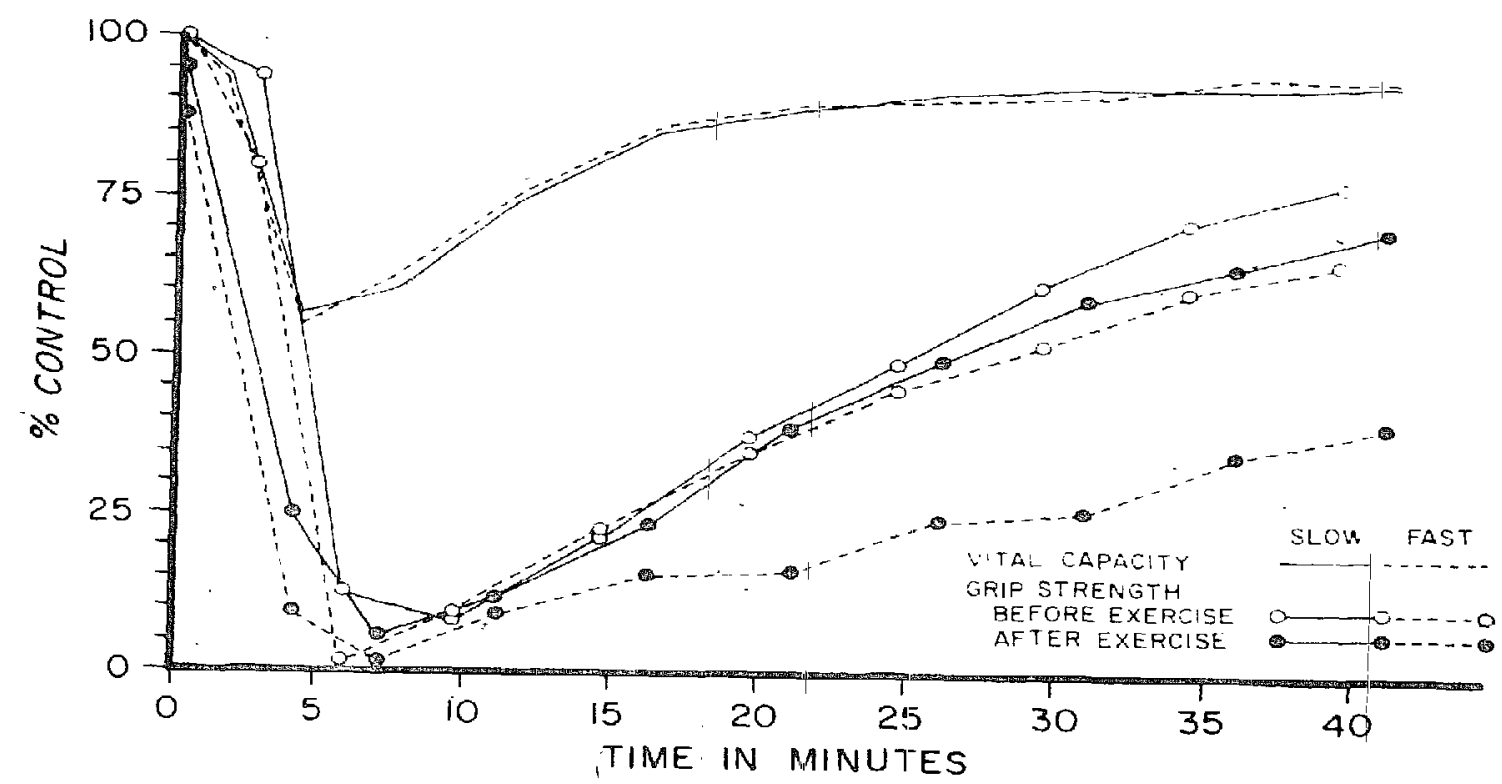

Figure 2. Effect of the rate of exercise on grip strength after the administration of $15 \mathrm{microgm} . / \mathrm{kg}$. toxiferine.

GALLAMINE TRIETHIODIDE (7OOMGM/KG:

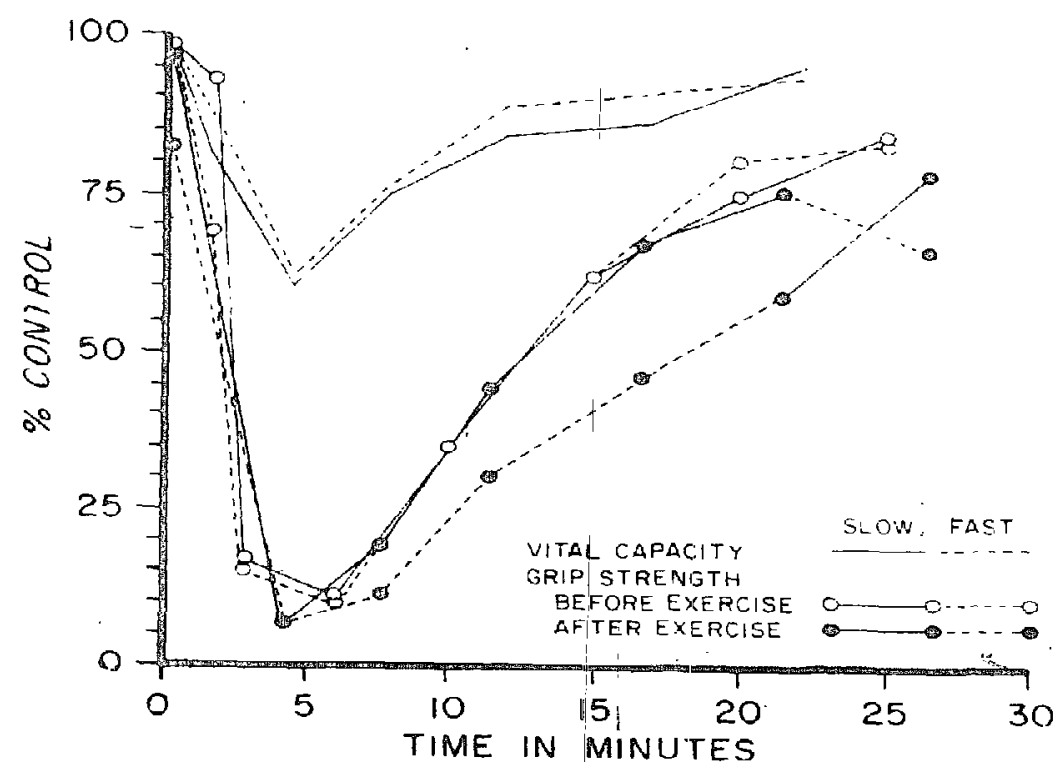

FIGURE 3. Effect of the rate of exercise on grip strength after the administration of $700 \mathrm{microgm} . / \mathrm{kg}$. gallamine. 
FOLDES et $a l .:$ EXERÇISE AND RELAXANT LiRUGS

DECAMETHONIUM BROMIDE (27 $\mu G M / K G)$

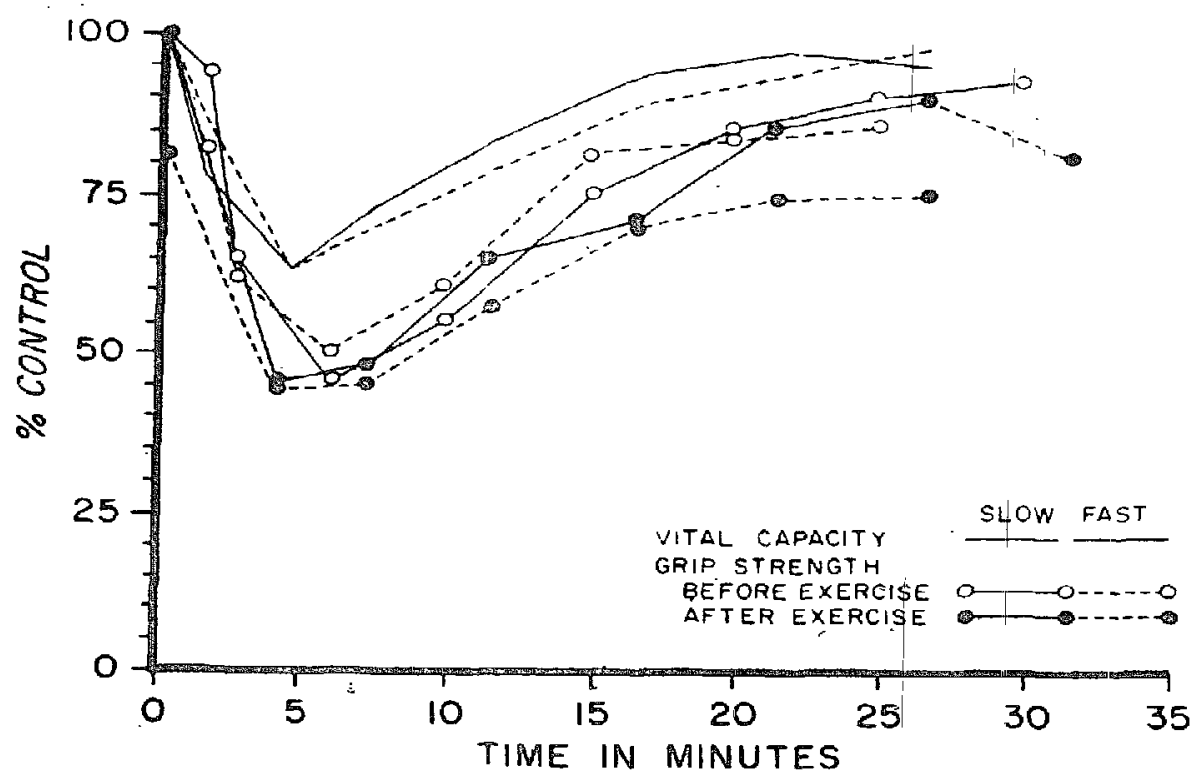

Figure 4. Effect of the rate of exercise on grip strength after the administration of $27 \mathrm{microgm} . / \mathrm{kg}$. ClO.

\section{SUCCINYLGHOLINE CHLORIDE (} PRECEDED BY HEXAFLUORENIUM (0.3 MG/KG)

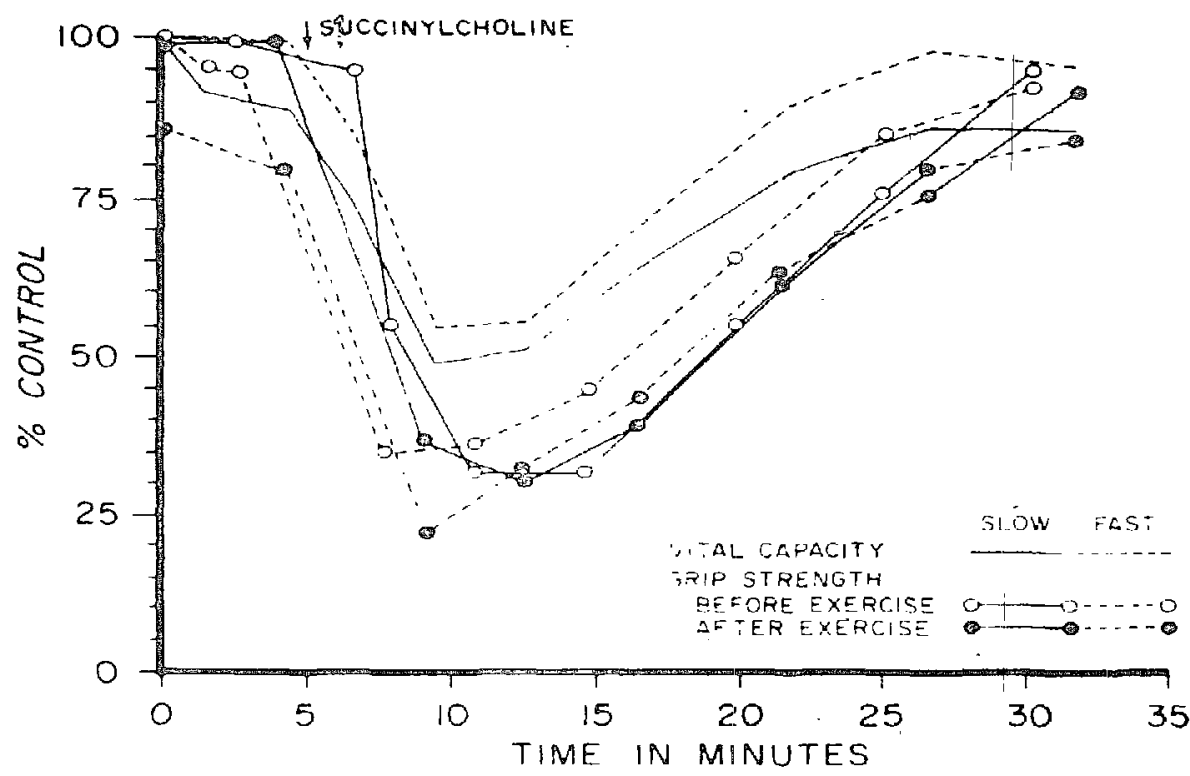

Figure 5. Effect of the rate of exercise on grip strength after the administration of 80 microgm. $/ \mathrm{kg}$. SCh. All subjects received 0.3 mig. $/ \mathrm{kg}$. hexafluorenium five minutes before the injection of $\mathrm{SCh}$. 
The difference in the effects of the rate of exercise on the grip strength after partial neuromuscular block produced by non-depolarizing and depolarizing relaxants is also evident from Figures $6,7,8,9$, and 10. After the use of nondepolarizing relaxants (Figs. 6, 7, and 8) with exercise at the rate of 60 per minute, there is a rapid decrease (fatigue) in the amplitude of the ergograph tracing. If the exercise is carried out at the rate of six per minute, there is little or no decrease in the grip scrength during exercise. In contrast, with the use of depolarizing relaxants (Figs. 9 and 10) the rate of exercise does not affect grip strength (no evidence of fatigue).

Subjects who received non-depolarizing relaxants and exercised at a slow rate until grip strength returned to 75 per cent of control and then five munutes later exercised at a fast rate sustained a marked decrease in grip strength (Figs. 1 and 3). Under these circumstances, the grip strength was about the same as when they exercised at a fast rate all through the experiment. Conversely, if after exercise at a fast rate throughout the experiment, the rate of exercise was slowed to six per minute at the end, the "after exercise" grip strength increased markedly to about the level reached if the subjects exercised at a slow rate throughout the experiment (Fig. 3).

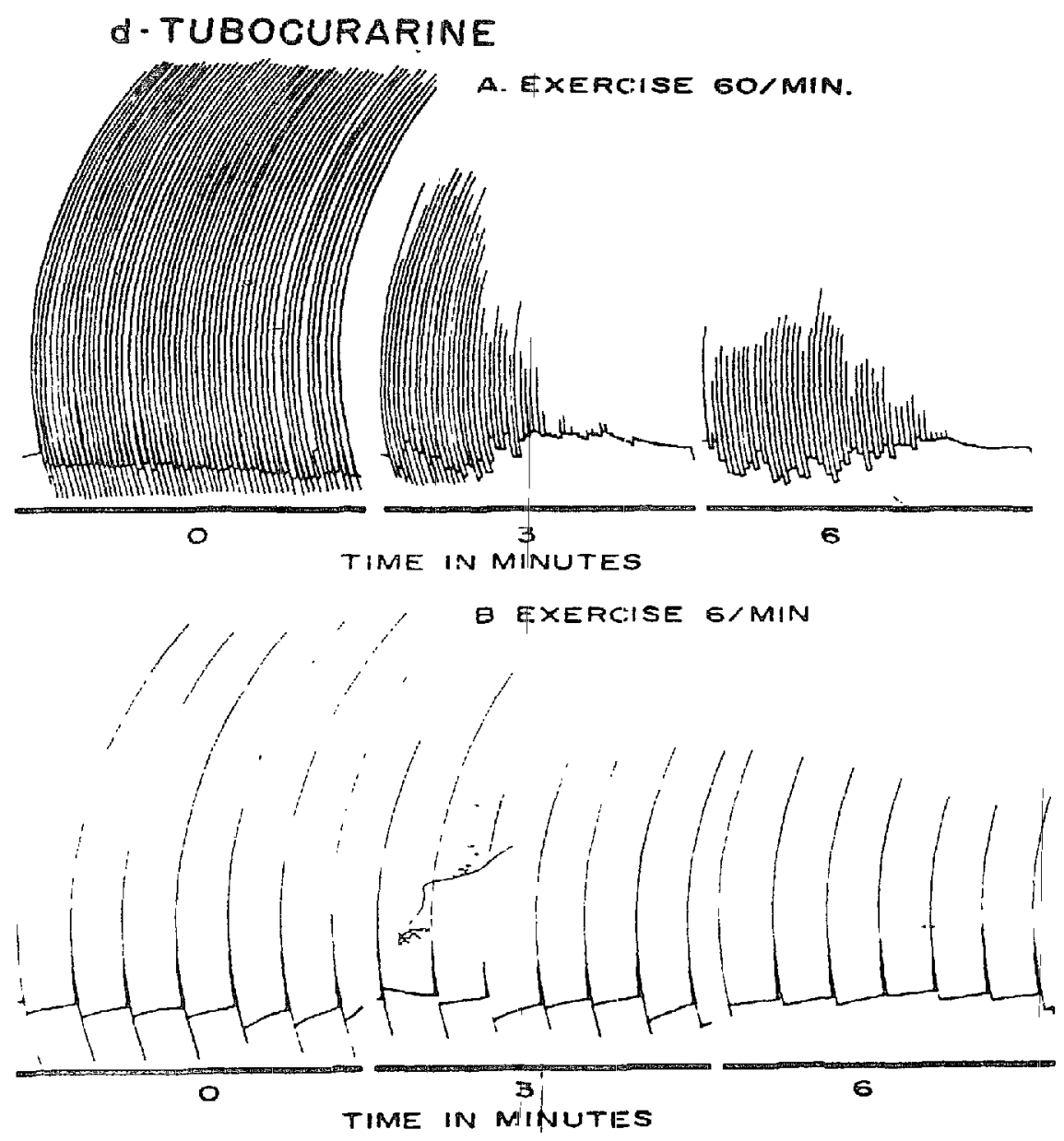

Figure 6. Ergograph tracings after the administration of $100 \mathrm{microgm} . / \mathrm{kg}$. d-Tc. Upper tracings, fast rate (note iatigue); lower tracings, slow rate (note absence of fatigue). 


\section{TOXIFERINE}

A. EXERCISE GO/MIN.
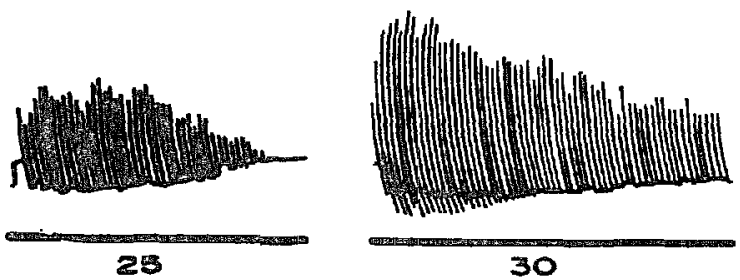

IN MINUTES

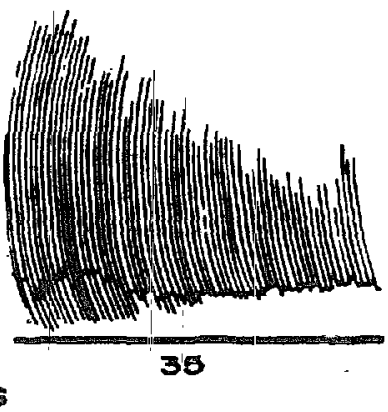

EXERCISE G/MIN.

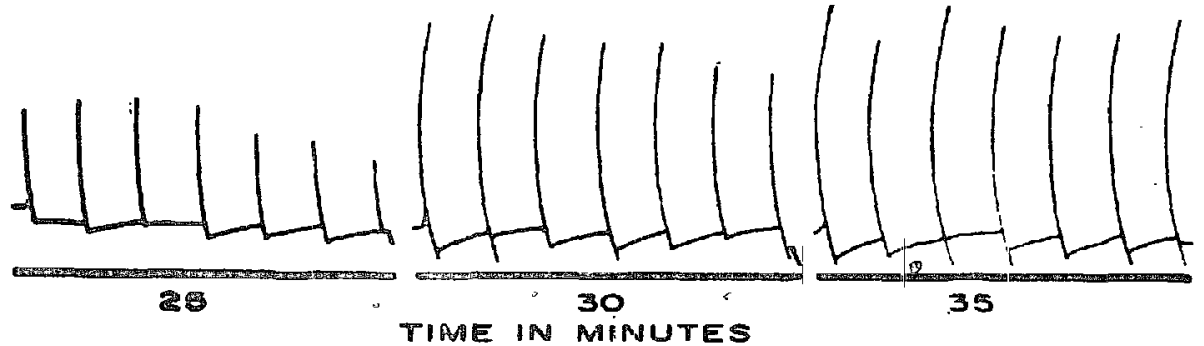

Figure 7. Ergograph tracings after the administration of $\mathbf{1 5}$ microgm./kg. toxiferine. Upper tracings, fast rate (note fatigue); lower tracings, slow rate (note absence of fatigue).

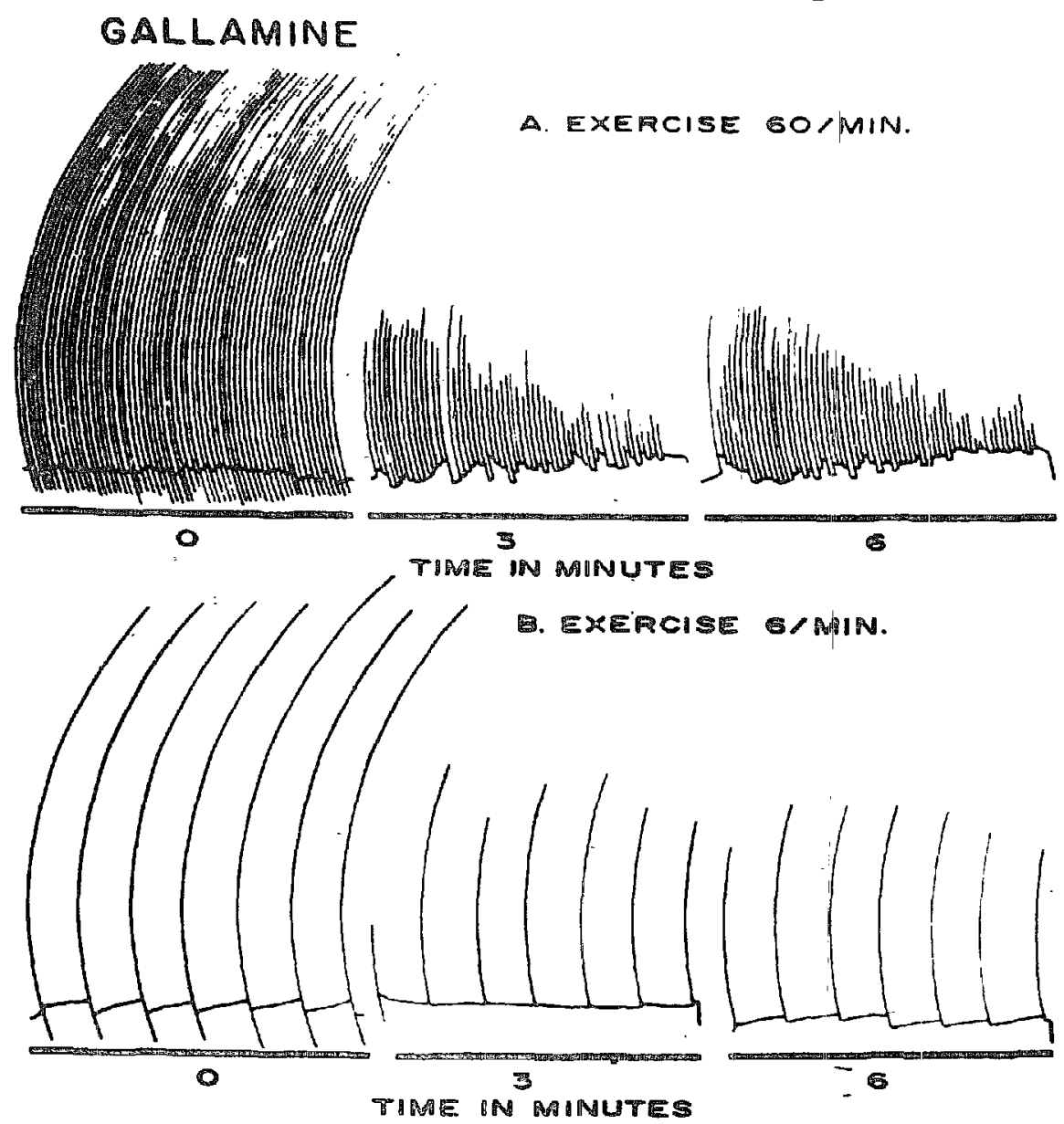

FIGURE 8. Ergograph tracings after the administration of $700 \mathrm{microgm} . / \mathrm{kg}$. gallamine. Upper tracings, fast rate (note fatigue); lower tracings, slow rate (note absence of fatigue). 


\section{DECAMETHONIUM}

A. EXERCISE GO/MIN.

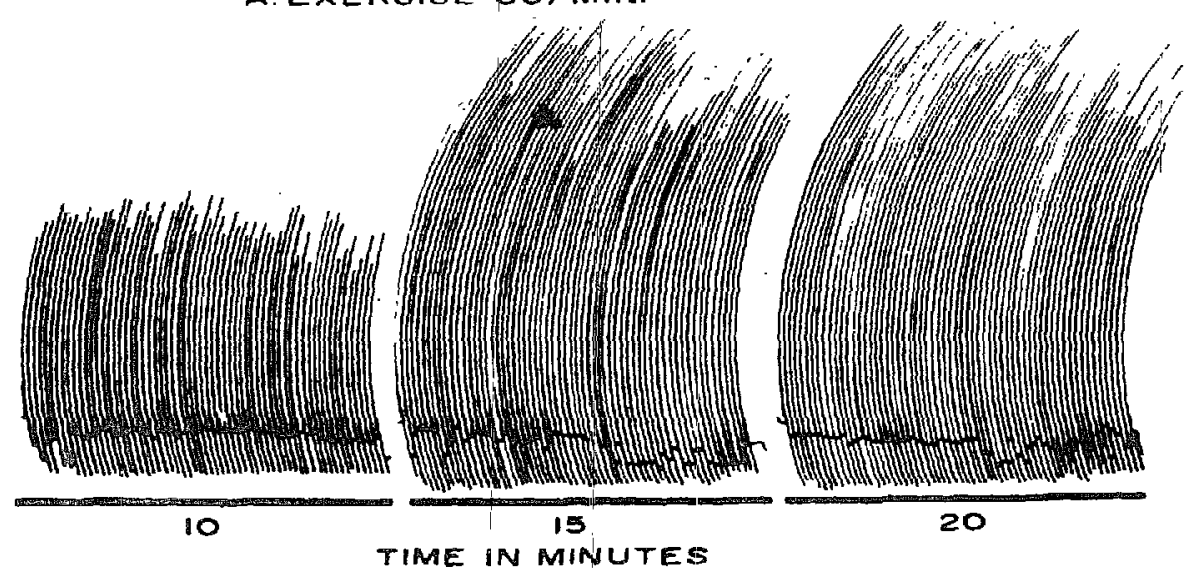

D. EXERCISE GIMIN.

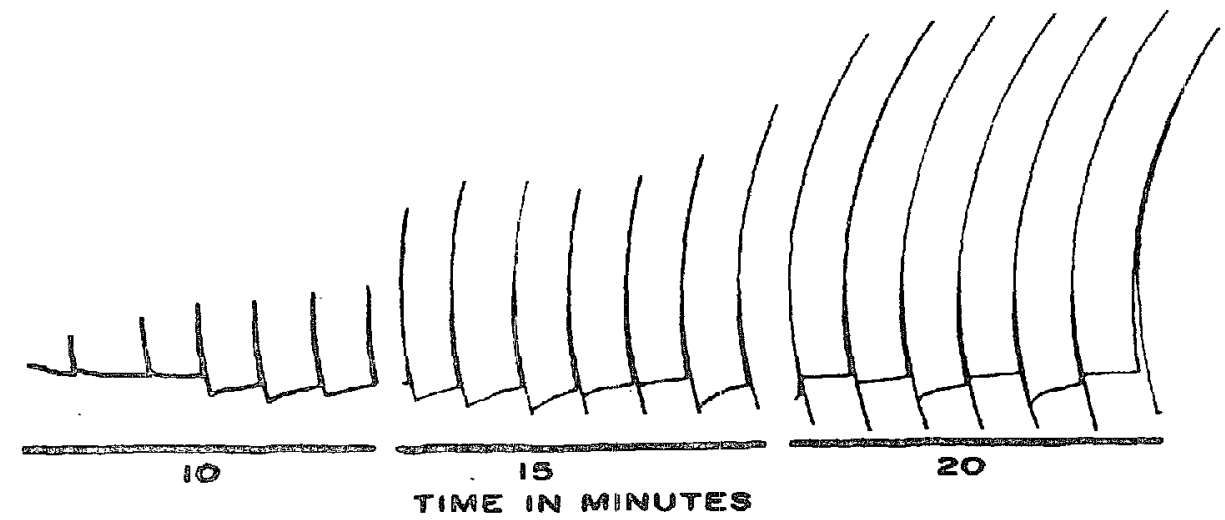

FIGLRE 9. Ergograph tracings after the administration of 27 microgm. $/ \mathrm{kg}$. ClO. Upper tracings, fast rate; lower tracings, slow rate. Note absence of fatigue after exercise at fast rate.

\section{COMMENTS}

The findings of this study are in agreement with those of Schmidt and Chase who found that previous exercise potentiated and prolonged the neuromuscular effects of $d-T c$ in rabbits. Both their findings and ours may be explained by the exhaustion of the acetylcholine reserves by exercise and a resiltant decrease in the quantity of acetylcholine released by the nerve impulse at the endplate. Since acetylcholine and $\mathrm{d}-\mathrm{Tc}$-are in conpetition for the cholinergic receptors of the endplate, decrease of the acetylcholine concentration will increase the effect of d-Tc. Although presumably the depolarizing relaxants also compete with acetylcholine for the cholinergic receptors, ${ }^{6}$ the depletion of the acetylcholine reserves by rapid exercise does not intensify and prolong the neuromuscular block in man. The depolarizing relaxants, similar to acetylcholine, increase the "lability" of the endplate 7.8 toward depolarizing influences, and during a partial block produced by these compounds the endplate region may be reversibly depolarized by smaller quantities of acetylcholine. It is also possible that while non-depolarizing relaxants interfere with the synthesis or release of acetvlcholine 


\section{SUCCINYLCHOLINE}

(PRECEDED BY HEXAFLUORENIUM)
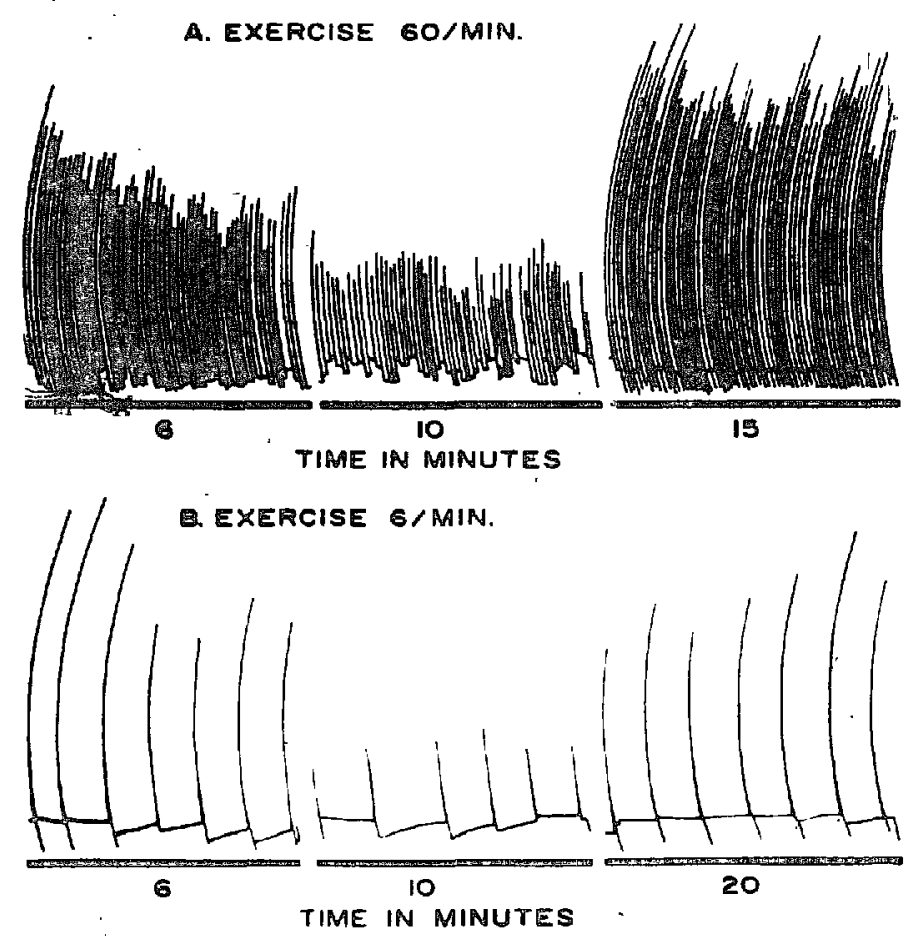

FigURE 10. Ergograph tracings after the administration of $80 \mathrm{microgm} . / \mathrm{kg}$. SCh preceded by $0.3 \mathrm{mg} . / \mathrm{kg}$. hexafluorenium. Upper tracings, fast rate; lower tracings, slow rate. Note absence of fatigue after exercise at fast rate.

at the neuromuscular junction, the depolarizing relaxants interfere to a lesser extent or not at all with these mechanisms. Interference with the acetylcholine synthesis or release has been postulated as the cause of the neuromuscular block induced by hemicholinium. ${ }^{9}$ It is of interest that the intensity of the hemicholinium block is also markedly influenced by the rate of stimulation.

With our experimental set-up, it was not possible to confirm the observation of Churchill-Davidson and Richardson ${ }^{10}$ that exercise shortened the duration of the $\mathrm{ClO}$ induced neuromuscular block. There is a good agreement, however, between the recent findings of Churchill-Davidson and $\mathrm{Christie}^{11}$ and the present findings. They observed in human subjects a gtadual decrease in the amplitude of the electromyogram induced by repeated indirect stimulation during partial neuromuscular block caused by d-Tc. No such decrease in the height of the electromyographic tracing was observed if the partial neuromuscular block was induced by $\mathrm{ClO}$.

Our findings also indicate that if the rate of exercise is six per minute or less, enough acetylcholine is released by the nerve impulse to maintain neuromuscular transmission at a constant level. It is also evident that the acetylcholine reserves, exhausted by rapid rate of exercise, recover within three to five minutes to the extent that there is no difference between the pre-exercise grip strength with slow or fast rate of exercise. 
The infuence of the rate of exercise on the partial neuromuscular block induced by non-depolarizing relaxants, besides its thedretical interest, may also have clinical significance. After the use of relaxant drugs, partial neuromuscular block is frequently present at the termination of anesthesia. After discontinuation of the assisted or controlled respiration, spontaneous respiratory activity may be seemingly adequate for a time. Later, however, the diaphragm may become exhausted, and if the patient is left unassisted, hypoxia and hypercarbia will develop. In extreme cases, fatigue of the partially "curarized" respiratory muscles may result in the patient's death. Anoxic deaths have been encountered in patients who had seemingly adequate spontaneous respiratory activity at the termination of the anesthesia and who were lef $t$ under inadequate supervision. Since in man, on prolonged administration, the properties of the neuromuscular block induced by depolarizing relaxants may become similar to those caused by non-depolarizing agents, ${ }^{12}$ the dangers of post-anaesthetic "recurarization" due to fatigue are also possible with non-depolarizing agents.

\section{SUMMARY}

1. The influence of the rate of exercise on the partial neuromuscular block produced by three non-depolarizing (d-Tc, toxiferine, and gallamine) and two depolarizing ( $\mathrm{ClO}$ and $\mathrm{SCh}$ ) relaxants was studied in ten healthy, adult, unanaesthetized subjects equally divided between the two sexes.

2. Exercise, which consisted of squeezing the bulb of an ergograph at the rate of six per minute, had no effect on the partial neuromuscular block, as measured by the grip strength, produced by either non-depolarizing, or depolarizing relaxants.

3. Similar exercise, but at the rate of 60 per minute, caused a rapid decrease of the grip strength if the partial neuromuscular block was induced by a nondepolarizing agent. No fatigue was observed under similar circumstances if the partial neuromuscular block was induced by a depolarizing relaxant.

4. Possible explanation of the findings presented and their clinical significance have been discussed.

\section{RÉSUME}

L'on a injecté par voie i.v. en 90 secondes, chez 5 hommes et 5 femmes adultes, bien portants, non anesthésiés, volontaires, dư chlorure de d-tubo-curarine, du triéthiodure de gallamine, du chlorure de toxiférine, du bromure de décaméthonium et du chlorure de succinylcholine, aux doses respectives de 100, 700, 15,27 et $80 \mathrm{micromg} / \mathrm{Kg}$. L'injection de succinylcholine a été précéclée de celle de $0,3 \mathrm{mg} / \mathrm{Kg}$ d'hexaffuorenium, par voie i.k., un inhibiteur plasmatique sélectif de la cholinestérase. On a noté la capacité vitale, la force de préhension, la T.A., le pouls et la fréquence respiratoire avant et à divers intervalles après l'administration des curarisants. La force de préhension a été mesurée immédiatement avant et après exercice consistant à presser la poire d'un ergographe durant une minute, puis une fois 6 fois/minute, et une autre fois 60 fois/minute. Aux doses utilisées, la diminution maximum de la force de préhension a été de 100 , 
90,65 et $55 \%$ avec respectivement la toxiférine, la gallamine, la d-tubocurarine, la succinylcholine et le décaméthonium. Les réductions correspondantes de la capacité vitale ont été de $45,40,12,50$ et $36 \%$ respectivement. La récupération de la capacité vitale ef́ de la force de préhension se font de façon parallèle avec la succinylcholine et le décaméthionium. Avec les autres agents, la capacité vitale revient plus rapidement à la normale que la force de préhension. Cette dernière est revenue à $75 \%$ dé sa valeur normale au bout de $15 \mathrm{~min}$. avec le décaméthonium, de $20 \mathrm{~min}$. avec la d-tubocurarine, la gallamine et la succinylcholine, et au bout d'environ $60 \mathrm{~min}$. avec la toxiférine. Des exercices pratiqués à un rythme rapide intensifient èt prolongent.de façon très marquée les effets de la d-tubocurarine, de la gallamine et de la toxiférine, mais non ceux du décamethonium et de la succinylcholine sur la force de préhension. Par contre des. exercices pratiqués à un rythme lent sont demeurés sans effet.

\section{REFERENCES}

1. Foldes, F. F. The Pharmacology of Neuromuscular Blocking Agents in Man. Clin. Pharmacol. Therap. $1: 345(1960)$.

2. Foldes, F. F.; Monte, A. P.; Brunn, H. M., Jr.; \& Wolfson, B. Studies with Muscle Relaxants on Unanesthetized Subjects. To be published (1960).

3. Wolfson, B., Foldes, F. F., \& Sokolz, M. Toxiferine: Experimental and Clinical Studies of its Neuromuscular Activity. Der Anaesthesist (In Press).

4. Foldes, F. F.; Hillmer, N. R.; Molloy, R. E.; \& Monte, A. P. Potentiation of the. Neuromuscular Effect of Succinylcholine by Hexafluorenium. Anesthesiology 21: 50 (1960).

5. Schmidt, J. L., \& Chase, H. F. Effect of Muscular Activity on Curarization in Rabbits. Proc. Soc. Exper. Biol. \& Med. 65: 13 (1947).

6. FoldEs, F. F. The Mode of Action of Quaternary Ammonium Type Neuromuscular Blocking Agents. Brit. J. Anaesth. 26: 394 (1954).

7. Shanes, A. M. Electrochemical Aspects of Physiological and Pharmacological Action in Excitable Cells: Resting Cell and its Alteration by Extrinsic Factors. Pharmacol. Rev. 10: 59 (1958).

8. Shanes, A. M. Electrochemical Aspects of Physiologicall and Pharmacological Action in Excitable Cells: Action Potential and Excitation. Pharmacol, Rev. 10: 165 (1958).

9. Reitzel, N. L., SR., \& Long, J. P. Neuromuscular Blocking Properties of the $\alpha, \alpha^{\prime}$-dimethylethanolamino-4,4'-biacetophenone (Hemicholinium). Arch. internat. "pharmacodyn. 119: $20(1959)$.

10. Churchill-Davidson, H. C., \& Richardson, A. T. Decamethonium lodide (ClO): Some observations in its Action Using Electromyography. Proc. Roy. Soc. Med. 45: 179 (1952).

11. Churchill-Davidson, H. C., \& Christie, T. H. The Diagnosis of Neuromuscular Block in Man. Brit. J. Anaesth. $31: 290(1959)$.

12. Foldes, F. F., Whuck, A. L.; Hodges, R. J. H:; Thesleff, S.; \& deBeer, E. J. The Mode of Action of Depolarising Relaxants. Anesth. \& Analg. 36: 23 (1957). 